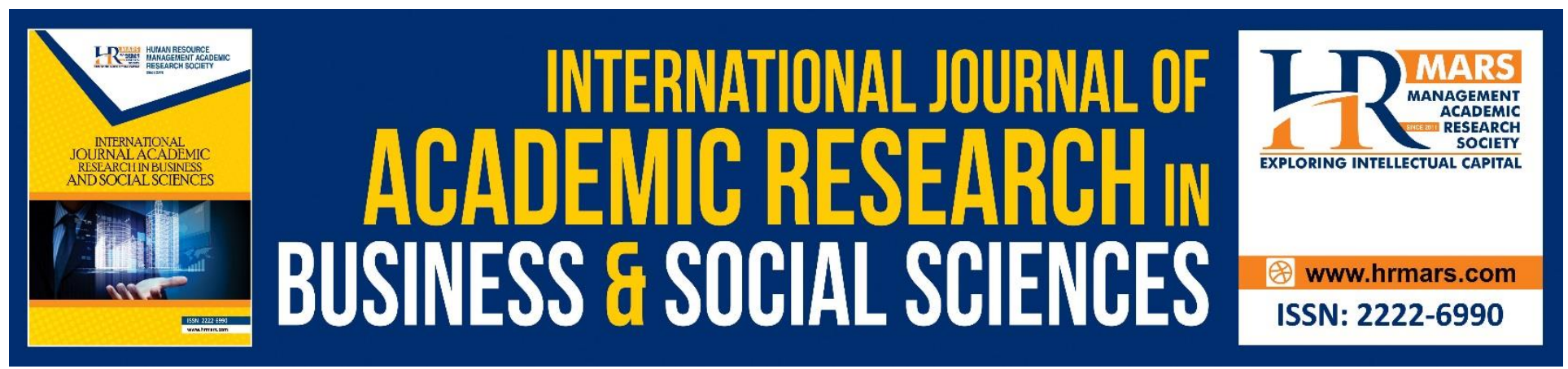

\title{
Determinants of Multidimensional Poverty Index of Niger State, Nigeria
}

\author{
Musa Mohammed, Rossazana Ab-Rahim
}

To Link this Article: http://dx.doi.org/10.6007/IJARBSS/v11-i14/8532

DOI:10.6007/IJARBSS/v11-i14/8532

Received: 29 November 2020, Revised: 25 December 2020, Accepted: 18 January 2021

Published Online: 30 January 2021

In-Text Citation: (Mohammed \& Ab-Rahim, 2021)

To Cite this Article: Mohammed, M., \& Ab-Rahim, R. (2021). Determinants of Multidimensional Poverty Index of Niger State, Nigeria. International Journal of Academic Research in Business and Social Sciences, 11(14), 95108.

Copyright: (c) 2021 The Author(s)

Published by Human Resource Management Academic Research Society (www.hrmars.com)

This article is published under the Creative Commons Attribution (CC BY 4.0) license. Anyone may reproduce, distribute, translate and create derivative works of this article (for both commercial and non-commercial purposes), subject to full attribution to the original publication and authors. The full terms of this license may be seen

at: http://creativecommons.org/licences/by/4.0/legalcode

Special Issue: Contemporary Business and Humanities Landscape Towards Sustainability, 2021, Pg. 95 - 108 http://hrmars.com/index.php/pages/detail/IJARBSS JOURNAL HOMEPAGE

Full Terms \& Conditions of access and use can be found at http://hrmars.com/index.php/pages/detail/publication-ethics 


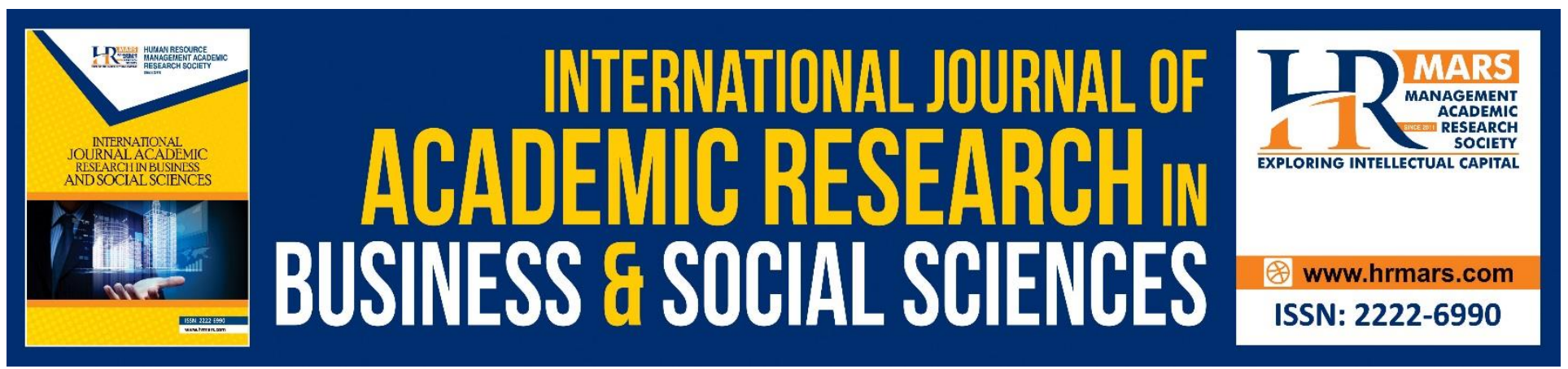

\title{
Determinants of Multidimensional Poverty Index of Niger State, Nigeria
}

\author{
Musa Mohammed, Rossazana Ab-Rahim \\ Faculty of Economics and Business Universiti Malaysia Sarawak, Sarawak. \\ Email: arrossazana@unimas.my
}

\begin{abstract}
Poverty as a concept is diverse, assorted, and multidimensional; nevertheless, the basic poverty measurement either the income or consumption methodology is inadequate to explain the multiple deprivations experienced by the poor. Hence, this study aims to construct a multidimensional poverty index of households in Nigeria using Alkire and Foster methodology. Next, this study also examines the determinants of multidimensional poverty among households. Questionnaire was employed to collect data from 432 households, and logit regression is used to assess the determinants of multidimensional poverty. The results show the households is 37 percent impoverished in terms of multidimensional poor; particularly, the living standard dimension. The findings also show higher education results fosters the well-being of the households, on contrary to the high number of children. The results of this study suggest efficient policies regarding general infrastructural development and encouragement of higher educational attainment will greatly contribute to poverty reduction.
\end{abstract}

Keywords: Determinants, Multidimensional Poverty Index, Alkire and Foster, Nigeria.

\section{Introduction}

Nigeria, undoubtedly, characterized as a nation that has experienced speedy economic growth yet worsening poverty. The state of the economy grew robustly annually more than an average of 6 per cent (\%) for last decade, despite the global financial crisis (International Monetary Fund, 2013), positioning Nigeria to be one of the fastest growing economies universally. However, despite this glaring growth performance, the poverty prevalence continued to increase, rising from $54 \%$ in 2004 to $72.1 \%$ in 2008, with an unsurpassed high of 74.6\% in 2012 (National Bureau of Statistics (NBS), 2014). On this note, the growth benefit has not been fairly distributed as the Gini coefficient, a universal gauge of inequality rose from $0.45 \%$ in 2010 to $0.48 \%$ in 2013 (Central Intelligence Agency, 2018). Consequently, the theoretical claims and empirical evidence that postulate the positive nexus between economic growth and poverty alleviation seems missing in the context of Nigeria. Hence, this motivates this study to embark upon the investigation of the multidimensional poverty in the Niger State of Nigeria and the determinants of poverty index. 
Adopting Alkire and Foster methodology (2011), the multidimensional poverty index (MPI) enlightens policymakers that the deprivation experienced by a human is not solely based on monetary; the government intervention programme targeted at poverty reduction should focus on non-monetary concerns as well. MPI helps to tackle sustainable development goals as well as fosters efficient and effective resources allocation by targeting those mostly pretentious by poverty.

The objective-list theory of well-being is built on the framework which spells out steps leading to elimination of poverty (Parfit, 1984; Griffin, 1986) and contains a list of strategies that contribute to poverty alleviation such as partnership, support, pleasure, achievement, autonomy, loving relationship and meaningful knowledge (Rice, 2013). Objective-list contains not only pleasant experience or desire-satisfaction as it also contains non-pleasant such as criminal activities that enhances well-being and decrease poverty. Objective theory of well-being shift from abstraction to practical items that enhance human well-being in the social system; it is an exit from less important items to more concrete list of items which could enhance the well-being (Fletcher, 2013).

In the same vein, Ukwayi et al. (2017); Parhoon et al (2014) suggests all factors that advances individuals' attainment and pleasure in society are included in objective-list theory of well-being. The authors further recommend that attainment of higher educational level increases income which allows an individual to afford choice of accommodation, pay hospital bills, eat nutritious food and send children to good schools to learn meaningful knowledge is important item in objective-list theory. These items include quality education for children, access to good health and improving living standard. Through attainment of some level of education by the people particularly the youth can lead to a higher income and will reduce multidimensional poverty to bearable minimum. Based on the above-discussed, the objective-list theory of well-being serves as the fundamental background of this study.

This paper continues as follows: next section presents a review of literature on the multidimensional poverty measurement and determinants of poverty; follows by the methodology section. The subsequent section presents the MPI and the results of determinants of poverty; the last section offers the conclusion part which summarizes the major findings and as well as policy implications.

\section{Literature Review}

A stream of past studies on poverty in Nigeria (Obah \& Onuoha, 2013; Ogbuabor et al., 2013; Ibrahim \& Ladan, 2014; Mamman et al., 2015; Alemu, 2019) has tended to focus on measuring the poverty based on monetary basis which is centered on income or expenditure base (i.e. money metric method), mostly utilized the poverty measurements by the United Nation Development Programme (UNDP), the National Bureau of Statistics and World Bank. The poverty measurement commonly used is set at $\$ 1.90$ for the extreme poverty (World Bank, 2015a). This poverty line describes a person to be considered poor if his or her income falls below a minimum level required in meeting basic needs. The well-known measurements are absolute and relative measure (Olowa, 2012). In the survey conducted by NBS reported in NBS Press Briefing on Nigeria Poverty Profile Report (2010), the relative poverty measurement of Nigeria in 2004 stood at 54.4\% and increased to 69\% in 2010; while absolute poverty was recorded at $54.7 \%$ in 2004 and rose to $60.9 \%$ in 2010 . This monetary approach has been 
criticized severely due to its failure to address other dimensions of poverty. Owing to this, recent studies began to apply multidimensional approaches in the study of poverty in Nigeria since its inception in 2010.

United Nation Development Programme (UNDP) has constructed the Human Development Index (HDI) as another option in determining the poverty status of a country either being under-developed, developing or developed, employing both economic and social indicators. The HDI encompasses three dimensions of education, health and living standard. Education is assessed by a combination of gross enrolment and adult literacy; health is assessed by life expectancy at birth, and living standard is assessed by GDP per capita. Thus, the HDI over a short period was not responsive to policy modifications. Consequently, the Human Poverty Index (HPI) was instituted to enhance HDI. The HPI, on the other hand, employed the concept of deprivation, through which poverty is seen as a situation whereby people are unable to meet up with their necessity of life.

The HDI assesses the average achievements in each dimension of education, health and living standard while HPI assesses deprivations in each dimension. The two measurements determine poverty status only at the national/regional level. The MPI is however introduced to complement both earlier measurements. The MPI determine poverty status not only at national/regional level but also at the household/individual level. Alkire et al. (2015); Dhongde and Haveman (2015) and Alkire and Santos (2010) instituted MPI as an aggregate measure of education, health and living standard. Education is assessed by year of schooling and school attendance. Health is assessed concerning nutrition and child mortality. Living standard put together a combination of stability of electricity; improve sanitation, water quality, flooring conditions, modern cooking fuel availability and asset conditions.

Alkire and Foster (2007) put forward a different weighting approach to determine the poor. Any individual/household deprived in a particular dimension will be assigned a particular weight. The aggregate weight is ranked between $0-1$. Equal weight is assigned to each dimension, so that, if it is $\mathrm{n}$-dimensions to be used, each dimension weight will be $1 / \mathrm{n}$. if a dimension is made up of many indicators, then, the weight for each indicator within the same dimension has the same value. Another cut-off is the number of dimensions that a deprived individual must experience to be classified as poor (Alkire \& Foster, 2011; Weziak-Bialowolska, 2014; Bardhi, 2017). The MPI measurement is different from other measurements of reports and statistics due to these two features: first, considering a person as poor count on the attainment of the entire household; second, MPI only considers deprivations of the multidimensionally poor (Santos \& Alkire, 2011; Oxford Poverty and Human Development Initiative, 2016). The MPI measurement has been used in several countries of the world. The Alkire and Foster's method (AFM) was applied by Awan et al. (2011) for multidimensional poverty measurement in Punjab Province, Pakistan. It employs eight dimensions of poverty: education, electricity, water land, housing, sanitation, expenditure, and assets. The results indicate that education, housing, land, expenditure, and sanitation formed the main contributors to the entire multidimensional poverty. Statistics South Africa (2014) measures MPI in South Africa using census data collected in 2001 and 2011 based on four dimensions of poverty: education, health, the standard of living and economic activity. The results show that the standard of living dimension 
contributed $45 \%$ to the multidimensional poverty, then, followed by economic activity dimension having $32.9 \%$ in 2001. In 2011, the standard of living dimension contributed $42 \%$; follows by economic activity with $39.8 \%$.

Past empirical studies have investigated a set of determinants of poverty and household welfare such as gender of the head of household, age of household, marital status, households living together, household headed by different couples, characteristics of household - household size, ratio of dependency, geographical factors - urban, rural and provisional dummies among others (Biyase \& Zwane, 2018). The level of education of the household head as a poverty determinant has mostly been observed to be the major contributor to severe poverty incidence (Edoumiekumo et al., 2013). The latter claims a household head whose highest attainment in educational was at the primary school stage, secondary school stage, tertiary stage was significantly prone to non-poor than as compared to those with no schooling.

The results of past studies also show the size of the household is a significant demographic variable that affects poverty. As confirmed by Khatun (2015), a household with many members possess a larger number of dependents and are prone to be poor compared with the smaller ones. Khatun also brought to light the relationship between age of the household head and poverty, which poverty affects mainly people who are either above or under-productive ages. Commonly, young people have low income due to their early involvement in the labour market begins with little earning and fewer hours of work. As the individual age progresses, there is a continuing achievement in education, work experience as well as labour network which simultaneously lead to an increase in income. Additionally, Rasak et al. (2014) suggest that women-headed households are most likely to be poor than the male-headed households. Due to gender discrimination, women particularly those in the rural areas lack education and asset which limit their access to better employment, shelter among others expose them to poverty.

\section{Methodology}

This study utilizes a quantitative survey to collect data from households in the Niger State of Nigeria; on this note, Niger State records the highest poverty rate at $61.20 \%$ in Nigeria follows by Benue State at $59.20 \%$. Past studies such as Ataguba et al. (2011) focus on assessing the determinants of poverty in rural areas while Adepoju (2018) measures the multidimensional poverty and its determinants; while the present study confines its analysis on the poorest state of Nigeria and investigates the socioeconomics factors towards the poverty alleviation in Niger State, Nigeria. Additionally, convenience sampling technique is adopted for the selection of 432 households as the respondents for selfadministrated questionnaires. The survey was conducted between November 2017 and April 2018 which was associated with high expectancy of democracy dividends by the masses and was unrealized due to corruption by the politicians. In the survey, the 5-point Likert scale was used, and the responses scored by $1,2,3,4$ and 5 , while 3 is a neutral position. The questions include the household demographic characteristics such as gender, educational level of household head, number of children and household size; and the three dimensions and ten indicators of poverty. 
The analytical methods employed in the analysis of data include the global MPI with three dimensions and ten indicators: and logit regression. The MPI of poor households in Niger State is constructed, while logit regression is employed to assess the determinants of poverty for household's classification as poor or non-poor in the measurement of multidimensional poverty.

\section{Model Specifications}

The 3 dimensions are equally weighted (1/3) and indicators in each dimensions are also equally weighted, for education and health (1/6 each), and for standard of living (1/18 each). To get the score $\left(c_{i}\right)$ of an individual household using weight $(w)$ and Indicator $(I)$ :

$$
\mathrm{C}_{\mathrm{i}}=\mathrm{w}_{1} l_{1}+w_{2} l_{2}+\ldots+w_{\mathrm{d}} l_{\mathrm{d}}
$$

Where $l_{1}-1$ if an individual is deprived in indicator $i$; $l_{1}-0$ otherwise.

The MPI combines two components: Multidimensional Headcount Ratio $(\mathrm{H})$; and Intensity of Poverty (A).

$$
H=\frac{q}{n}
$$

where $q$ - the number of people that are multidimensional poor; $n$ - total population.

$$
A=\frac{\sum_{i=1}^{n} c_{i}(k)}{q}
$$

where $c_{i}(k)$ - the censored deprivation score of individual household $i ; q$-number of those that are multidimensional poor.

However, the MPI is the outcome (product) of the two components:

$$
\mathrm{MPI}=\mathrm{H}^{*} \mathrm{~A}
$$

A score of $33.3 \%$ (one third of the weighted indicators) is used to differentiate between the poor and non-poor. If the deprivation score of a household is $33.3 \%$ or greater, such household (or its members) is classified as multidimensional poor. Table 2 shows the categories of poor in terms of MPI computations. To predict whether a household is poor or non-poor (dependent variable, poor = 1 , non-poor $=0$ ) using household characteristics (independent variables). The identities of the logit model are as below:

The logit identities relate independent variable $X$ to the rolling mean of dependent variable $(P)(\bar{Y})$ as follow:

$$
P=\frac{e^{a+b X}}{1+e^{a+b X}}
$$

Or

$$
P=\frac{1}{1+e^{-(a+b X)}}
$$

where $\mathrm{P}$ - the probability of a 1 (the proportion of $1 \mathrm{~s}$, the mean of $\mathrm{Y}$ ); $\mathrm{e}$ - is the base of the natural logarithm; $a$ and $b$ - are the parameters of the model.

The value of a yields $P$ when $X$ is zero, and $b$ adjusts how quickly the probability changes with changing $X$ a single unit. Adding household characteristics components into equation we have 


$$
P(Y=1)=\frac{e^{a+b C H}}{1+e^{a+b C H}}
$$

where $\mathrm{P}(\mathrm{Y}=1)$ - the probability of being poor; $\mathrm{CH}$ - household characteristics.

\section{Results and Discussion}

\section{Descriptive Statistics}

The descriptive analysis in Table 1 shows that, about $56.9 \%$ of the respondents are male and around $77.1 \%$ are married and mostly educated with no less than first school certificate. Larger percentage of the respondents have children between 4 to $8(56.3 \%)$ and $68.3 \%$ has household size between 4 to 10 members. In terms of their personal monthly income, about $94 \%$ receives below 50,000 with $88.4 \%$ of the respondents do not save much.

\section{Multidimensional Poverty Index}

Table 3 shows the summary of the result of multidimensional poverty index of Niger State of Nigeria. Based on Table 3, 62\% $(\mathrm{H})$ is multidimensional poor, which signifies that they are in severe poverty. They are deprived of a minimum of entire indicators of a single dimension or a combination across dimensions. In addition, the poor in the Niger State are deprived in 59\% (A) of the weighted indicators. The common poor person is $59 \%$ deprived of the weighted indicators, and as such $59 \%$ is the intensity of poverty. The $62 \%(\mathrm{H})$ realized is adjusted by the intensity of poverty $(59 \%)$ and that the State is deprived in 37\% (MPI) of the aggregate deprivations which may be experienced in general. Since the deprivation score of Niger State of Nigeria is greater than 33.3\% (one third of the weighted indicators), the State is classified as multidimensional poor.

The MPI classification of the respondents as severe poor, poor, near poor and non-poor is presented in Table 4. About 201 of the respondents are classified as multidimensional severe poor i.e. they are deprived of more than $50 \%$ of the weighted indicators. Majority of the respondents are deprived of more than half of the weighted dimensions and indicators of poverty, that is they enjoy only a little of the basic requirement of life them. About 72 respondents are classified as multidimensional poor i.e. they are deprived of more than $33 \%$ and less than $50 \%$ of the weighted indicators. This category indicates that, despite being poor, they are not in abject poverty, that is they enjoy some basic requirement of life, but not up to minimum. Furthermore, 30 respondents are classified as near multidimensional poor, because they are deprived of more than $20 \%$ and less than $33 \%$ of the weighted indicators. This signifies that they are not poor, but highly vulnerable. While 126 of the respondents are classified as multidimensional non-poor i.e. they are deprived of less than $20 \%$ of the weighted indicators. This shows that, this class of respondents enjoy more than minimum of the basic requirement of life. This outcome indicates that a larger proportion of people in the Niger State of Nigeria are multidimensionally poor.

Figure 1 shows each dimension contribution to the entire deprivation faced by those categorized as multidimensional poor (cut-off point, above $\mathrm{k}=0.33$ ). Standard of living dimension which consists of electricity, sanitation, drinking water, cooking fuel, flooring and assets contributed more than half $(63 \%)$ to the total deprivations experienced by the poor. This indicates that there is a general 
infrastructural decay in Niger State and Nigeria at large. Even though Nigerian government has launched a series of infrastructural development, but the result seems very slow to earn. Health dimension which comprises of nutrition and child mortality contributed $27 \%$, this portrays that health care facilities, particularly of secondary type, are inadequate in Nigeria. The Nigerian government couples with donor agencies and individuals on several occasions do organize free secondary health care treatment aiming to provide health for all, but the effectiveness of the programmes remain unanswered. Education dimension which comprises of school attendance and child enrolment contributed only $10 \%$. This lower percentage can be attributed to free basic education of the first nine years of schooling initiated by the Nigerian government since the return of democratic government in 1999.

\section{Determinants of Monetary and Multidimensional Poverty (Logit Regression)}

Table 5 shows that 273 households representing about $62 \%$ of the respondent are multidimensional poor. The rate of the poverty measure is very high in Nigeria; this coincides with earlier findings of Oxford Poverty and Human Development Initiative (2016) which submits that Nigeria is among the five countries of the world with larger proportion of her population (53.3\%) in multidimensional poor. Based on the logit regression analysis, the independent variables is the household characteristics (gender, marital status, level of education, number of child and household size) while the dependent variable is the determination of poverty category (poor or non-poor). Therefore, logit regression measures the impact of household characteristics on poverty determinants. The analysis of logit model is projected by the estimation of the maximum likelihood with robust standard errors. From the analysis, the educational level and number of children are significant at $p<0.1$ and $p<0.10$ respectively. Meanwhile, the household characteristics of gender, marital status and household size are not significant. The logit model estimation results are shown in Table 6.

For the characteristics of household, the logit analysis results indicate each one of the family characteristics varies in terms of gender, marital status, level of education, number of child and household size. The negative coefficient associated with educational level variable signifies that a higher attainment of educational level by the head of the household result in a greater probability of being non-poor. This outcome concord with the earlier findings of Edoumiekkumo et al. (2013) that, a household head whose highest attainment in education was at the level of primary, secondary, tertiary schools were likely not to be poor compared with that of no education. Also, stated by Rasak et al. (2014) that, a male headed household have more tendencies than a female one due to gender discrimination, and therefore, the former are likely to be non-poor as compared to the later. Conversely, the positive sign associated with number of children signifies that household with larger number of children experience a higher degree of likelihood of being poor in multidimensional measurement of poverty. This is in consonant with findings of Khatun (2014) that, a household having many members are attributed to large number of dependents and are liable to be poor as compared to those with smaller ones.

However, the insignificant of household characteristics of gender, marital status and household size does not invalidate the outcome, this is because, it was concluded in the literature that the level of education is the most important variable that explain the chronic poverty incidence (Edoumiekumo, Karimo, \& Tombofa, 2013; Olofin, Adejumo, \& Sanusi, 2015; Shete, 2010; Spaho, 2014). The partial 
(marginal) effect of the determinant of level of education is that, the likelihood of being multidimensional poor will reduce by $0.814 \%$, if the household head moves a step further in educational attainment like from primary completion to secondary completion. On the other hand, for the determinants of number of children, the likelihood of being multidimensional poor hope to increase by $0.526 \%$, if the number of children increased by one.

\section{Conclusions}

The description of poverty is beyond a single phenomenon; its nature is diverse and multidimensional. In the Nigeria context, that is demographically and socio-economically diverse, the monetary poverty measurement is insufficient to comprehensively capture the deprivation experienced by the poor. This study employed AFM structure to estimate poverty and as well to classify the poor in Nigeria. The method analyzed data on three dimensions of poverty: education, health and standard of living, with ten indicators within the dimensions. The outcome of the study indicates that $62 \%$ of the population is multidimensionally poor, and the common poor are $59 \%$ deprived of the weighted indicators. However, Niger State is deprived in $37 \%$ (MPI) of the total deprivations which classified the State as multidimensional poor and standard of the living dimension of well-being is the major contributor. The results of the study imply that people of the study area lacks adequacies of regular electricity, improve sanitation, clean drinking water, good house floor, modern cooking fuel and many assets which comprised of living standard dimension of poverty.

The study affirmed that higher attainment of educational level by the head of the household result in a greater probability of being non-poor. That is, the likelihood of being multidimensional poor will reduce by $0.814 \%$ if the household head moves a step further in educational attainment. The study also affirmed that effective policies towards general infrastructural development and encouragement of higher educational attainment will greatly contribute to poverty reduction.

This study contributes to the literature gap in the context of Niger State being the pioneer study in the area of multidimensional poverty in the state, it also makes a contribution to the empirical understanding of multidimensional poverty and in particular as it relates to it estimations. Finally, it contributes to the objective-list theory by offering explanations of the extent of achievement across the combination of the list (dimensions and indicators of well-being) of items for improved wellbeing.

The policy recommendation of the study upholds that people should be encourage attain higher educational level; maintain minimal number of children to reduce their probability of being poor. Conversely, the major limitation of the study was basically resources and time constraints which limit the sample of the study to 8 LGAs out of 25; it may lead to possibly bias in the findings being generalized to the whole study area. Based on this limitation, a future study on multidimensional poverty in Niger State should cover the entire state, and findings can possibly be unbiased and can be generalized to country at large. 
INTERNATIONAL JOURNAL OF ACADEMIC RESEARCH IN BUSINESS AND SOCIAL SCIENCES

Vol. 11, No. 14, Contemporary Business and Humanities Landscape Towards Sustainability. 2021, E-ISSN: 2222-6990 @ 2021HRMARS

\section{Acknowledgement}

This work was supported by Ministry of Higher Education and Universiti Malaysia Sarawak [grant numbers F01/FRGS/1607/2017].

\section{References}

Adepoju, A. (2018). Determinants of multidimensional poverty transitions among rural households in Nigeria, Paper presented at the Proceeding of the International Association of Agricultural Economists 2018, Vancouver, British Columbia.

Alemu, Z. G. (2019). Poverty in Nigeria: A multidimensional approach, AfDB Working Paper No. 327. Abidjan, Côte d'Ivoire: African Development Bank.

Ataguba, J., Fonta, W. M., \& Ichoku, H. E. (2011). The determinants of multidimensional poverty in Nsukka, Nigeria (PMMA Working Paper 2011-13). SSRN Electronic Journal. Retrieved from https://ideas.repec.org/p/ags/peppbr/164434.html

Alkire, S., \& Foster, J. (2007). Counting and multidimensional poverty measurement (Vol. OPHI Working Paper 7). Oxford, UK: University of Oxford.

Alkire, S., \& Foster, J. E. (2011). Counting and multidimensional poverty measurement. Journal of Public Economics, 95(7-8), 476-487.

Alkire, S., \& Foster, J. E. (2011). Counting and multidimensional poverty measurement. Journal of Public Economics, 95(7-8), 476-487.

Alkire, S., Foster, J., Seth, S., Santos, M. E., Roche, J. M., and Ballon, P. (2015). Multidimensional poverty measurement and analysis. Oxford: Oxford University Press.

Alkire, S., \& Santos, M. E. (2010). Acute Multidimensional Poverty: A New Index for Developing Countries. SSRN Electronic Journal. Retrieved from http://ssrn.com/abstract=1815243.

Bardhi, R. (2017). An analysis of monetary and multidimensional poverty measurements in Albania (multidimensional poverty index). European Journal of Business, Economics and Accountancy, 5(4), 32-43.

Biyase, M., \& Zwane, T. (2018). An empirical analysis of the determinants of poverty and household welfare in South Africa. The Journal of Developing Areas, 52(1), 115-130.

Central Intelligence Agency. (2018). The world fact book. Retrieved from https://www.cia.gov/library/publications/the-world-factbook/rankorder/2172rank.html

Dhongde, S., \& Haveman, R. (2015). Multi-Ddimensional poverty index: An application of the United State, IRP Discussion Paper No. 1427-15. Wisconsin-Madison: Institute for Research on Poverty.

Edoumiekumo, S., Karimo, T., \& Tombofa, S. (2013). Determinants of households' poverty and vulnerability in Bayelsa State of Nigeria. International Journal of Humanities and Social Science Invention, 2(2), 14-23.

Fletcher, G. (2013). A fresh start for the objective list theory of well-being. Utilities, 25(2), 206-220.

Ibrahim, S. A., \& Ladan, Z. (2014). The role of small scale enterprises in poverty reduction in rural areas of Sokoto State. International Letters of Social and Humanistic Sciences, 32, 197-203.

IMF. (2013). Nigeria: 2012 Article IV Consultation (Vol. Country Report 13/116). Washington, DC: International Monetary Fund.

Khatun, R. (2015). The impact of micro-level determinants of poverty in Bangladesh: A field survey. International Journal of Research in Management and Business Studies, 2(2), 9-13. 
Mamman, A., Kanu, A. M., Alharbi, A., \& Baydoun, N. (2015). Small and medium-sized enterprises (SMEs) and poverty reduction in Africa: Strategic management perspective. Newcastle: Cambridge Scholars Publishing.

National Bureau of Statistics (NBS). (2014). The Nigeria Poverty Profile 2014. Report of the National Bureau of Statistics Harmonized Nigeria Living Standard Survey (HSNLSS). (2014 Report). Abuja, Nigeria: National Bureau of Statistics.

NBS Press briefing on Nigeria Poverty Profile Report. (2010). The Nigeria poverty profile 2010 report. Retrieved from https://reliefweb.int/sites/reliefweb.int/files/resources/b410c26c2921c18a6839baebc9b14 28fa98fa36a.pdf

Oba, U. O., \& Onuoha, B. C. (2013). The role of small and medium scale enterprises in poverty reduction in Nigeria: 2001 - 2011. An International Multidisciplinary Journal, Ethiopia, 7(4), $1-25$.

Ogbuabor, J. E., Malaolu, V. A., \& Elias, T. I. (2013). Small scale enterprises, poverty alleviation and job creation in Nigeria: Lessons from burnt bricklayers in Benue State. Journal of Economics and Sustainable Development, 4(18), 120-133.

Olofin, O. P., Adejumo, A. V., \& Sanusi, K. A. (2015). Determinants of poverty level in Nigeria. Journal of Sustainable Development, 8(1), 235-241.

Olowa, O W. (2012). Concept, measurement and causes of poverty: Nigeria in perspective. American Journal of Economics, 2(1), 25-36.

Oxford Poverty and Human Development Initiative. (2016). Nigeria country briefing, multidimensional poverty index data bank. OPHI, university of oxford. Retrieved from www.ophi.org.uk/multidimensional-poverty-index/mpi-country-briefings/

Oxford Poverty and Human Development Initiative. (2017). "Morocco Country Briefing", Multidimensional Poverty Index Data Bank. OPHI, University of Oxford. Retrieved from https://www.ophi.org.uk/wp-content/uploads/Morocco1.pdfhttps://www.ophi.org.uk/wpcontent/uploads/Morocco1.pdf

Parhoon, K., Parhoon, H., \& Movallali, G. (2014). Effectiveness of Training Sensory Stimulation on Gross Motor Skills of 5-7 Years Old Children with Down Syndrome. International Journal of Academic Research in Psychology, 1(1), 22-31

Rice, C. M. (2013). Defending the objectives list theory of well-being. Ratio, 26(2), 196-221.

Santos, M. E., \& Alkire, S. (2011). Training material for producing national human development reports. Retrieved from https://www.ophi.org.uk/wp-content/uploads/MPI-Primer1.pdf

Shete, M. (2010). Magnitude and determinants of rural poverty in Zeghe Peninsula, Ethiopia. Journal of Poverty, 14, 308-328.

Spaho, A. (2014). Determinants of poverty in Albania. Journal of Educational and Social Research, 4(2), 157-163. Statistics South Africa. (2014). The South African MPI: Creating a multidimensional poverty index using census data (Vol. Report no.: 03-10-08). Pretoria, South Africa: Statistics South Africa.

Ukwayi, J. K., Angioha, P. U., \& Ojong-Ejoh, M. U. (2017). Youth empowerment: A criminological approach for crime prevention and control in Cross River State, Nigeria. IOSR Journal of Humanities and Social Science, 22(11), 73-81. 
INTERNATIONAL JOURNAL OF ACADEMIC RESEARCH IN BUSINESS AND SOCIAL SCIENCES

Vol. 11, No. 14, Contemporary Business and Humanities Landscape Towards Sustainability. 2021, E-ISSN: 2222-6990 @ 2021HRMARS

Weziak-Bialowolska, D. (2014). Spatial variation in EU poverty with respect to health, education and living standards. Social Indicators Research, 125(2), 451-479.

World Bank. (2015a). FAQs: Global poverty line update. Retrieved from http://www.worldbank.org/en/topic/poverty/brief/global-poverty-line-faq

\section{Appendix}

\begin{tabular}{|c|c|c|c|c|c|}
\hline Demographic & $\begin{array}{l}\text { Frequency } \\
\text { (n) }\end{array}$ & $\begin{array}{l}\text { Percentage } \\
\text { (\%) }\end{array}$ & Demographic & $\begin{array}{l}\text { Frequency } \\
\text { (n) }\end{array}$ & $\begin{array}{l}\text { Percentag } \\
\text { e (\%) }\end{array}$ \\
\hline Gender & & & $\begin{array}{l}\text { Number of } \\
\text { child }\end{array}$ & & \\
\hline Male & 246 & 56.9 & $1-3$ & 106 & 24.5 \\
\hline \multirow[t]{2}{*}{ Female } & 186 & 43.1 & $4-8$ & 243 & 56.3 \\
\hline & & & $9-13$ & 49 & 11.3 \\
\hline Age & & & 14 and above & 26 & 6 \\
\hline $21-28$ & 79 & 18.3 & & & \\
\hline $29-36$ & 88 & 20.4 & $\begin{array}{l}\text { Household } \\
\text { size }\end{array}$ & & \\
\hline $37-44$ & 135 & 31.3 & $1-3$ & 83 & 19.2 \\
\hline \multirow[t]{2}{*}{45 and above } & 130 & 30.1 & $4-6$ & 151 & 35.0 \\
\hline & & & $7-10$ & 148 & 34.3 \\
\hline Marital status & & & $11-14$ & 43 & 10.0 \\
\hline Single & 20 & 4.6 & 15 and above & 7 & 1.6 \\
\hline Married & 333 & 77.1 & & & \\
\hline Divorce & 10 & 2.3 & $\begin{array}{l}\text { Personal } \\
\text { monthly } \\
\text { income }(\mathrm{N})\end{array}$ & & \\
\hline Separated & 8 & 1.9 & $\begin{array}{l}\text { Less than } \\
50,000\end{array}$ & 406 & 94.0 \\
\hline \multirow[t]{2}{*}{ Widow } & 61 & 14.1 & $\begin{array}{l}51,000- \\
100,000\end{array}$ & 22 & 5.1 \\
\hline & & & $\begin{array}{l}101,000- \\
150,0000\end{array}$ & 4 & 0.9 \\
\hline \multicolumn{6}{|l|}{$\begin{array}{l}\text { Education } \\
\text { status }\end{array}$} \\
\hline No school & 116 & 26.9 & $\begin{array}{l}\text { Monthly } \\
\text { savings (N) }\end{array}$ & & \\
\hline $\begin{array}{l}\text { Primary } \\
\text { education }\end{array}$ & 8 & 1.6 & $\begin{array}{l}\text { Less than } \\
50,000\end{array}$ & 425 & 98.4 \\
\hline $\begin{array}{l}\text { Secondary } \\
\text { education }\end{array}$ & 122 & 28.2 & $\begin{array}{l}51,000- \\
100,000\end{array}$ & 7 & 2.8 \\
\hline $\begin{array}{l}\text { Tertiary } \\
\text { education }\end{array}$ & 186 & 43.1 & & & \\
\hline \multicolumn{6}{|c|}{ Respondents ( $N=432$ ) } \\
\hline
\end{tabular}


Table 1: Respondents Background Information

\begin{tabular}{|l|c|}
\hline MPI Cut-off & MPI Classification \\
\hline$C_{i}>0.50$ & Severe poor \\
\hline$C_{i} \geq 0.33$ to $\leq 0.50$ & Poor \\
\hline$C_{i} \geq 0.20$ to $<0.33$ & Near poor \\
\hline$C_{i}<0.20$ & Non-poor \\
\hline
\end{tabular}

Table 2: MPI Classification

\begin{tabular}{|l|c|c|c|}
\hline Indicators & $\mathrm{H}$ & $\mathrm{A}$ & $\mathrm{MPI}=\mathrm{H}^{*} \mathrm{~A}$ \\
\hline 432 & 0.62069 & 0.5997 & 0.37223 \\
\hline
\end{tabular}

$\begin{array}{ll}\text { Indicators }= & \begin{array}{l}\text { Number of Respondents } \\ \mathrm{H}=\end{array} \\ \mathrm{Aultidimensional} \text { Head count Ratio or the percentage of people } \\ \text { who are poor }\end{array}$

Table 3: Summary of Multidimensional Poverty Index Of Niger State

\begin{tabular}{|l|c|c|}
\hline MPI Cut-off & Number of Respondents & MPI Classification \\
\hline$C>0.50$ & 201 & Severe poor \\
\hline$C \geq 0.33$ to $\leq 0.50$ & 72 & Poor \\
\hline$C \geq 0.20$ to $<0.33$ & 30 & Near poor \\
\hline$C<0.20$ & 129 & Non-poor \\
\hline Total & 432 & \\
\hline
\end{tabular}

Table 4: Summary of The MPI Classification of The Respondents

\begin{tabular}{|l|c|c|}
\hline Variables & \multicolumn{2}{|c|}{ Multidimensional poor } \\
\hline & Mean & SD \\
\hline Household Characteristics & & \\
\hline Gender & 0.63 & 0.483 \\
\hline Marital status of household head & 0.63 & 0.483 \\
\hline Level of education & 0.63 & 0.483 \\
\hline Number of child & 0.64 & 0.479 \\
\hline Household size & 0.64 & 0.479 \\
\hline Number of observation & \multicolumn{2}{|c|}{273} \\
\hline
\end{tabular}


INTERNATIONAL JOURNAL OF ACADEMIC RESEARCH IN BUSINESS AND SOCIAL SCIENCES

Vol. 11, No. 14, Contemporary Business and Humanities Landscape Towards Sustainability. 2021, E-ISSN: 2222-6990 @ 2021HRMARS

Table 5: Descriptive Data of Poverty Status

\begin{tabular}{|c|c|c|c|}
\hline & Coefficient & Robust S.E. & $\mathrm{P}$-value \\
\hline $\begin{array}{l}\text { Household } \\
\text { Characteristics }\end{array}$ & & & \\
\hline Gender & 0.113 & 0.298 & 0.704 \\
\hline $\begin{array}{l}\text { Marital status of } \\
\text { household }\end{array}$ & -0.159 & 0.133 & 0.230 \\
\hline Level of education & -0.814 & 0.131 & $0.000 * * *$ \\
\hline Number of child & 0.526 & 0.308 & $0.087^{*}$ \\
\hline Household size & -0.003 & 0.209 & 0.987 \\
\hline Constant & 3.857 & 0.989 & $0.000 * * *$ \\
\hline Wald Chi-Square & \multicolumn{3}{|c|}{60.73} \\
\hline Prob Chi2 & \multicolumn{3}{|c|}{0.001} \\
\hline $\begin{array}{l}\text { Log Pseudo } \\
\text { Likelihood }\end{array}$ & \multicolumn{3}{|c|}{-195.51144} \\
\hline Pseudo R2 & \multicolumn{3}{|c|}{0.2919} \\
\hline $\begin{array}{l}\text { Number of } \\
\text { observation }\end{array}$ & \multicolumn{3}{|c|}{432} \\
\hline
\end{tabular}

Table 6: Estimated Result of Logit Regression of Poverty Determinants

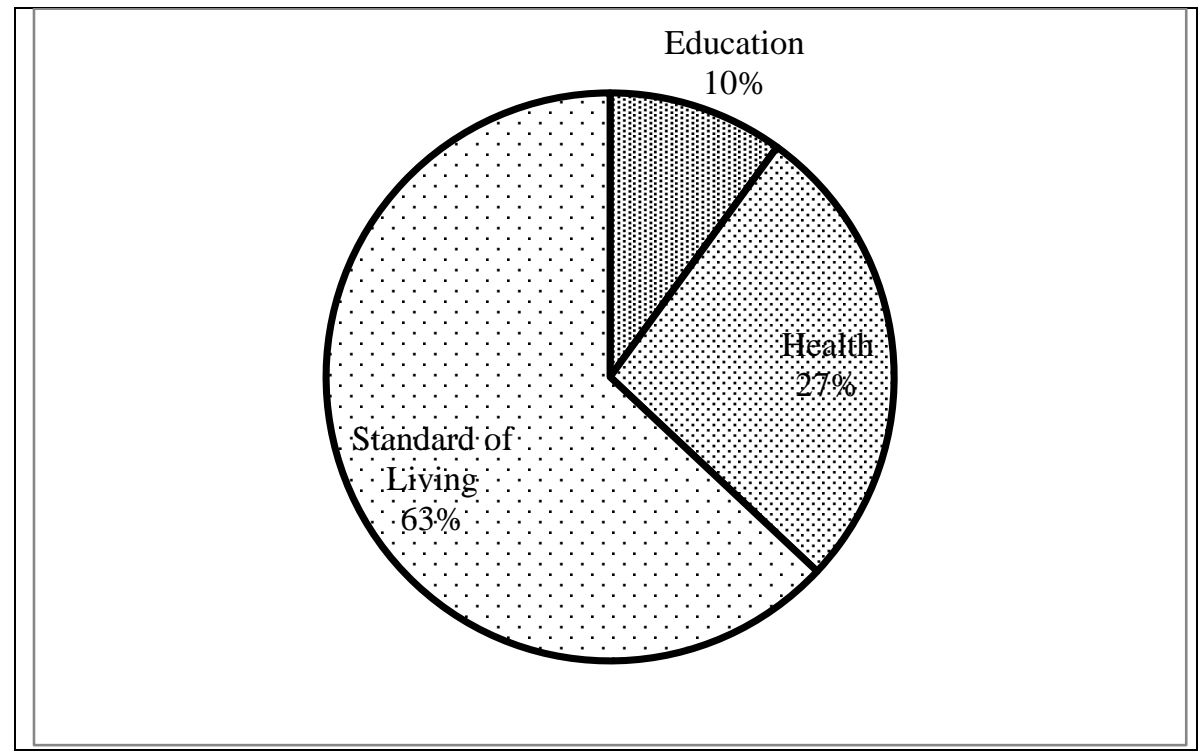

Figure 1: Poverty Drivers of Multidimensional Poor 